\title{
Antimicrobial Activity of Ferns
}

\author{
Samir Kumar Pal \\ P.G department of Botany, Darjeeling Govt. College, Darjeeling, 734101, W.B., India
}

\begin{abstract}
The present aim is the study of ferns having antimicrobial activity and commonly found around the area of district Darjeeling of West Bengal, India. Common ferns from several areas of Darjeeling district are collected and tested against Gram +ve and Gram-ve bacteria for their antimicrobial activity. Collected plant materials are dried and the soluble extracts are made using different solvents like distilled water, methanol, ethanol and acetone Antimicrobial activities are measured using agar cup diffusion method. Greater the area of inhibition zone indicates the presence of good potentiality of antimicrobial activity. A large number of common ferns are collected and among them some species are found having antimicrobial activity. Five species show antimicrobial activity against both gram $+v e$ and gram -ve bacteria.
\end{abstract}

Key Words: antimicrobial, extract, gram positive and gram negative, inhibition zone, solvent .

\section{Introduction}

The medicinal value of ferns has been known to many for more than 2000 years. The Greek botanist Theophrastus (C. 372 - 287 B.C.) has referred to the medicinal value of ferns in his book Historia Plantarum. A systematic survey of antimicrobial activity of ferns have been made by Banerjee \& Sen (1980), Sen \& Nandi (1981) and Maruzzella(2005). They found that the fern extracts are effective against both gram +ve and gram ve bacteria. Glands of epidermal hairs on leaves and rhizomes contain chemicals that are found to have antimicrobial activity.

Medicinal ferns of India are studied and listed by Nayer (1959), , Dhiman (1998), Singh et al (2001). Kirtikar \& Basu (1935) have described 27 species of ferns having varied medicinal uses. Nayar (1959) recorded 29 medicinal ferns. May (1978) published a detailed review the uses of ferns and listed 105 medicinal ferns. The antimicrobial potential of some ferns has also been studied by Kumar (1999), Parihar \& Bohar (2002, 2003).

\section{Material and Methods}

Freshly collected specimens were dried at $40^{\circ} \mathrm{C}$ in Hot-air-oven for $3-5$ days and then powdered. Leaf extract is made from powdered specimens in distilled water and in different organic solvents like methanol, ethanol and acetone successively. For each specimen and for each extraction $5 \mathrm{gm}$ powder is taken in three conical flasks $(100 \mathrm{ml})$ to which $20 \mathrm{ml}$ solvent is poured respectively and shacked for about 24 hours at room temperature $37^{0} \mathrm{C}$. The extracts are filtered and used.

The filtered extracts are tested for antimicrobial activities against both gram positive and gram negative bacteria on nutrient agar plate by disc diffusion method (Bauer et al 1966). The bacterium E. coli is taken as standard gram negative specimen and the bacterium Bacillus megaterium is taken as standard gram positive specimen for testing the antimicrobial activity.

In present experiment fresh bacterial culture solution having concentration $10^{6}$ cells/ml is taken and discs of $6 \mathrm{~mm}$ in diameter are made on nutrient agar plate for diffusion assay. Sterile distilled water is used as control. After incubation for 24 hours at $37^{\circ} \mathrm{C}$, the diameter of inhibition zones are measured and analyzed. Three replicates are made for each set of experiment.

Protein was determined by the method of Lowry et al (1951)

\section{Results}

In the present work, at first the ferns having antimicrobial activity are screened and selected. The result is presented in Table-1,2 and 3 . The specimen numbered 1,2, 5, 6, 7and 10, exhibit positive effect against gram positive bacterium, the specimen numbered 1,2, 5, 7, 8 and 10, exhibit positive effect against gram negativeve bacterium and the specimen numbered 1, 2, 5, 7 and 10 exhibit positive effect against both gram negative and gram positive bacteria. The specimens having positive antimicrobial effect are selected for further studies and are identified as Athyrium filix-femina(L.)Roth.(1), Dicranopteris linearis(Burm.f.)Underw.(2),Tectaria impressa(Fee.)Holtum.(5) ,Hypolepis punctata(Thunb.)Mett.(7), Pleopeltis macromarpa(Bory ex Willd.)Kaulf(10), The specimen number sp 2,5and10 show good antimicrobial activity against gram positive bacterium The specimen number sp2, 7, 8 and 10 show good activity against gram negative bacterium. Athyrium filix-femina has better activity against gram negative bacteria than gram positive bacteria. Dicranopteris linearis has almost equal activity against both gram positive and gram negative bacteria. Tectaria impressa also 
shows similar activity against both gram positive and gram negative bacteria but it is less active than Dicranopteris linearis Hypolepis punctata has more activity against gram positive bacteria than gram negative bacteria. Pleopeltis macrocarpa shows good activity against both gram positive and gram negative bacteria. Ethanol is an organic solvent and helps to extract non polar substances from the dried plant materials that have antimicrobial activity.

Table-1 Activity of Ethanol extract against Bacillus megaterium

\begin{tabular}{|c|c|c|c|}
\hline Specimen No & $\begin{array}{c}\text { Inhibition } \\
\text { area(mm) }\end{array}$ & Protein $(\mathrm{mg} / \mathrm{ml})$ & $\mathrm{pH}$ \\
\hline Sp1 & 8.5 & 0.0046 & 6.8 \\
\hline Sp2 & 10.2 & 0.0032 & 7.0 \\
\hline Sp3 & - & - & - \\
\hline Sp4 & - & - & - \\
\hline Sp5 & 9.5 & 0.0045 & 6.9 \\
\hline Sp6 & 7.5 & 0.0034 & 6.8 \\
\hline Sp7 & 8.8 & 0.0036 & 7.2 \\
\hline Sp8 & - & - & - \\
\hline Sp9 & - & - & - \\
\hline Sp10 & 11.2 & 0.0037 & 7.0 \\
\hline
\end{tabular}

Table -2 Activity of Ethanol extract against E.coli

\begin{tabular}{|c|c|c|c|}
\hline $\begin{array}{c}\text { Specimen } \\
\text { No }\end{array}$ & Inhibition area(mm) & Protein $(\mathrm{mg} / \mathrm{ml})$ & $\mathrm{pH}$ \\
\hline $\mathrm{Sp} 1$ & 9.7 & 0.0046 & 6.8 \\
\hline $\mathrm{Sp} 2$ & 10.4 & 0.0032 & 7.0 \\
\hline $\mathrm{Sp} 3$ & - & - & - \\
\hline $\mathrm{Sp} 4$ & - & - & - \\
\hline $\mathrm{Sp} 5$ & 9.8 & 0.0045 & - \\
\hline $\mathrm{Sp} 6$ & - & - & 7.0 \\
\hline $\mathrm{Sp} 7$ & 10.6 & 0.0036 & 6.9 \\
\hline $\mathrm{Sp} 8$ & 11.2 & 0.0040 & - \\
\hline $\mathrm{Sp} 9$ & - & - & 7.0 \\
\hline $\mathrm{Sp} 10$ & 11.5 & 0.0037 & \\
\hline
\end{tabular}

Table-3 Activity of Ethanol extract of selected species

\begin{tabular}{|l|l|l|l|l|}
\hline Specimen No & $\begin{array}{l}\text { Ecoli } \\
(\mathrm{mm})\end{array}$ & B.megaterium $(\mathrm{mm})$ & Protein(mg/ml) & $\mathrm{pH}$ \\
\hline Sp1 Athyrium filix-femina & 9.7 & 8.5 & 0.0046 & 6.8 \\
\hline Sp2 Dicranopteris linearis & 10.2 & 10.4 & 0.0032 & 7.0 \\
\hline Sp5 Tectaria impressa & 9.5 & 9.8 & 0.0045 & 6.9 \\
\hline Sp7 Hypolepis punctata & 8.8 & 10.6 & 0.0036 & 7.0 \\
\hline Sp10 Pleopeltis macrocarpa & 11.2 & 11.5 & 0.0037 & 7.0 \\
\hline
\end{tabular}

\section{Conclusion}

The leaf blade and rachis of ferns are covered by glands densely. These epidermal glands (Manikam,2002) contain substances like phenolic compounds, glycosides, flavonoids. and alkaloids(Alcaraz et al200,Cushnie and Lamb2005, Yusuf1994). These substances are largely responsible for the antimicrobial activity and are being soluble in organic solvents easily extracted in methanol, ethanol and acetone but less soluble in water(Adedapo et al,2009, Banerjee and sen1980)

The present results show the good antimicrobial activity of four species indicating the presence of good amount substances like phenolic compounds, glycosides, flavonoids and alkaloids. These observations are good agreement with the findings of Sen and Nandi(1951), Banerjee and Sen(1980), Natarajan et al(2005). The antimicrobial activities of the ferns are also in agreement with the common usage of ferns in folk medicine for bacterial infection such as infection of throat, boil, ulcer and in wound healing(Banerjee and Sen 1980), tumour(Creasey 1969), dermatophytes(Davvamani et al 2005).

The antibiotic spectra of four ferns cover both gram positive and gram negative bacteria. These observations provide support that the ferns produce a variety of antimicrobial substances. It is necessary to keep in mind that the factors like climatic condition, nature of plant parts, age of plant at the time of collection etc are also responsible for the enhancement of the activity of the antimicrobial substances and it needs to be studied more in details.

The amounts of protein present in the extract show little variation though antimicrobial activities show wide variation among the specimens. It indicates that proteins may have little effect on antimicrobial activities. 


\section{Acknowledgement}

The author is thankful to the director of UGC (ER) for providing the financial assistance by granting a minor project. The author is also thankful to the principal and the head of the P.G. department of Botany, Darjeeling Govt. College for providing all laboratory facilities. The author convey his gratitude to Prof. Radhanath Mukherjee, Department of Botany, the University of Burdwan for helping to identify the ferns

\section{References}

[1] R.D Banerjee, S.P Sen ,Antibiotic activity of Pteridophytes. Ecol. Bot1980., 34(3): 284-298.

[2] S.P Sen, P Nandi :Antibiotics from the pteridophytes. Sci. Cult 1951., 16: 328-329.

[3] J.C Maruzzella :Antimicrobial substances from ferns. Nature2005,1961.,191: 518-519.

[4] A.W Bauer, M.M Kirby, J.C Sherris, M Truck Antibiotic susceptibility testing by a standardized single disk method. Am J Clin Pathol 1966; 45: 493-6.

[5] O.H Lowry,., N.J. Rosebrough, A.L. Farr, and R.J. Randall (1951) Protein Measurement with the Folin Phenol Reagent. J. Biol. Chem. 193:265-275

[6] V.S Manickam ,A Benniamin ,V Irudayaraj Antibacterial activity of leaf glands of Christells parasitica (L.) Lev, Indian Fern J2002., 22: $87-88$

[7] L.E Alcaraz, S.E Blanco ,O.N Puig, F Tomas ,F.H Ferretti : Antibacterial activity of flavonoids against methicillin-resistant Staphylococcus aureus strains. J Theor Biol 2000., 205:231-240.

[8] T.P.T Cushnie ,A.J Lamb : Antimicrobial activity of flavonoids. Int J Antimicrob Agents 2005., 26:343-356.

[9] U.K Yusuf : Flavonoid Glycosides in the Fern Blechnum orientale Linn. AmF J 1994., 84:69-70.

[10] D Natarajan , G Perumal ,C Mohanasundari ,K Moorthy , Studies of antimicrobial activities of certain medicinal ferns against selected dermatophytes, Indian Fern J2005., 22: 191-195.

[11] W.A Creasey ,Antitumoral activity of the fern Cibotium schiedei Nature1969., 222: 1281-1282

[12] S.N Davvamani ,J Gowrishankar,G Anbuganpathi ,K Srinivasan ,M.L Dhar, M.M Dhar, B.N Dhawan ,B.N Mehrotra ,C Roy , Screening of Indian plants for biological activity, Part I. Indian J. Exp. Biol 1968., 6: 232-247. 